ISSN 1979-7540

\title{
PENENTUAN RUGI TRANSMISI JARINGAN SISTEM TENAGA LISTRIK DENGAN PEMBAGIAN PROPORSIONAL
}

\author{
Irman Amri \\ Dosen Fakultas Teknik Universitas Al-Amin Muhammadiyah Sorong
}

\begin{abstract}
Abstrak
Penelitian ini bertujuan untuk menentukan nilai rugi rugi dari transmisi system tenaga listrik secara proporsional dengan metode penelusuran aliran daya. Pendekatan dalam metode ini dilakukan secara proporsional berdasarkan kontribusi bagian dari sistem. Penelitian dilakukan dengan menggunakan dua keadaan yang antara keduanya dibedakan dengan besarnya daya yang terbangkitkan. Hasil penelitian menunjukkan bahwa dari aliran daya diketahui besar rugi daya sistem Sulawesi selatan sebesar 19,46 atau kurang lebih 3,31 \% (keadaan 1) dan sebesar 3,34 \% untuk kondisi setelah masuknya pembangkit Barru (keadaan 2). Proporsi kontribusi terhadap rugi daya terbesar berasal dari Pusat Pembangkit Listrik Tenaga Air di Bakaru (No Bus 2 ) untuk kedua keadaan yaitu sebesar 35,14\% untuk keadaan 1 dan 28,1 \% untuk keadaan 2, serta kontribusi terkecil 0,07\% (keadaan 1) dan 0,042\% (keadaan 2) semuanya dari PLTD Mamuju.
\end{abstract}

Kata kunci $\quad$ : Rugi Daya, aliran daya, proporsional.

\section{PENDAhUluAN}

\subsection{Latar Belakang}

Di indonesia jagung merupakan salah satu komoditi strategis dan bernilai ekonomis serta mempunyai peluang untuk dikembangkan karena kedudukannya sebagai sumber utama karbohidrat dan protein yang mensubstitusi beras. Nilai kalori jagung hampir sama dengan beras bahkan jagung mempunyai keunggulan bila dibandingkan dengan beras disebabkan jagung mengandung asam lemak esensil yang sangat bermanfaat bagi pencegahan penyakit arteriosclerosis, yakni semacam penyempitan pembuluh darah. Selain itu kandungan minyak jagung yang non kolesterol ini juga dapat mencegah penyakit Pellegra (penyakit kulit kasar), (Warisno,1998).

Sebagai sumber karbohidrat kedua setelah beras, jagung memegang peranan penting sebagai bahan pangan di Indonesia. Selain sebagai bahan pangan, jagungpun dimanfaatkan sebagai bahan makanan ternak dan bahan baku industri dengan tingkat kebutuhan yang besar. Bahkan penggunaan

\section{PENDAHULUAN}

Di dalam penyediaan tenaga listrik dapat dibedakan secara jelas tiga fungsi : pembangkitan, penghantaran dan distribusi
(Stevenson, 1994) yang mungkin dapat dianggap sebagai produksi, pengangkutan dan penjualan eceran tenaga tersebut. Pembangkitan, yaitu produksi tenaga listrik, dilakukan dalam pusat-pusat tenaga listrik atau sentral-sentral, dengan menggunakan generator-generator. Sedangkan transmisi atau penghantaran adalah memindahkan tenaga listrik ini dari pusat-pusat tenaga listrik secara besar-besaran ke tempat-tempat tertentu, yang dikenal dengan gardu induk. Dari gardu -gardu induk ini tenaga listrik didistribusikan ke gardu-gardu distribusi, kemudian ke para pelanggan atau konsumen. Fasilitas-fasilitas pembangkitan dan transmisi biasanya kait-mengait secara ekonomis, dalam pilihan lokasi, desain dan hubungan ekonomi skala. Sering terjadi, bahwa penugasan organisasi dari pembangkitan dan transmisi dilakukan bersamaan, sedangkan distribusi sering diusahakan sendiri.

Rugi-rugi transmisi yang saat ini jumlahnya cukup signifikan secara nasional yaitu $2,26 \%$ dan 4,82 \% untuk Sulawesi selatan sesuai data tahun 2006 (www.pln.go.id), hal ini menyebabkan perhitungan biayanya pun penting untuk diperhitungkan. Bagaimana menentukan nilai rugi-rugi dari transmisi telah menjadi 
ISSN $1979-7540$

pemikiran yang sangat utama oleh pelaku pasar tenaga listrik (H.Sahkali,2007) .

Kebijakan pemerintah dengan dikeluarkannya UU ketenagalistrikan No. 40 Tahun 2003 yang yang kemudian dibatalkan pihak Mahkamah Kontitrusi namun kembali menjadi Rancangan UU yang akan disahkan pada tahun 2009 ini sebelum habisnya masa jabatan Anggota DPR RI periode 2004-2009 (Fajar Makassar, Akhir Mei 2009), akan semakin membuka peluang hadirnya pihak swasta untuk ikut bersama sama dengan PLN untuk melayani kebutuhan listrik yang konsekwensinya kemudian adalah semakin memperketat perhitungan perhitungan biaya biaya yang akan dibebankan pada masyarakat.

Apakah metode yang selama ini digunakan oleh PT.PLN (Persero) dalam menentukan besar rugi daya. Berapakah besar rugi-rugi Daya yang ada dalam sebuah sistem jika dilihat dari peran masing masing pembangkit terhadap Rugi tersebut, menjadi hal yang penting untuk diteliti.

\section{TINJAUAN PUSTAKA}

\section{A. Aliran Daya}

Aliran daya adalah sebuah istilah yang diberikan untuk sebuah kondisi jaringan yang memperlihatkan besar arus, tegangan dan aliran daya pada setiap bus dalam sistem. Normalnya aliran daya diasumsikan berada dalam keadaan sistem yang seimbang dan aliran dayanya selalu menghasilkan persamaan solusi yang positif. Studi aliran daya tidaklah menghitung sebuah jaringan tunggal seperti menghitung $\mathrm{E}=\mathrm{IR}$ atau $\mathrm{E}=$ Z I yang analisis sirkuitnya dimulai dengan mencari arus atau tegangannya dan jawabannya akan linier (Allen $J$ Wood dan Bruce L.W, 1984. P65).

Studi aliran daya umumnya digunakan secara rutin untuk perencanaan, control dan operasi dari sebuah sistem tenaga termasuk untuk perencanaan perluasan kedepannya. Dalam operasi sistem tenaga , studi aliran daya digunakan untuk mengevaluasi keadaan sistem dalam kondisi operasi yang ada dan untuk mendeteksi kondisi kemungkinan kelebihan beban, serta mengevaluasi batas-batas pengalihan supplai pada beban. Dalam studi aliran daya juga bisa dilakukan analisis kontingensi untuk mengetahui efek jika terjadi kelebihan beban atau lepasnya sebuah generator (James A.Momoh, 2001.p65).

\section{B. Susut Daya Dalam Transmisi ( Transmission Losses )}

Besar rugi-rugi daya pada saluran transmisi berbanding lurus dengan kuadrad arus yang dilewatkannya (Allen $J$ Wood dan Bruce $L . W, 1984 . p 79)$. Arus yang dilewatkan ke saluran transmisi akan selalu berubah ubah menyesuaikan dengan perubahan beban yang terjadi, sehingga rugi-rugi daya memiliki kecenderungan untuk berubah.

Perhitungan rugi daya secara sederhana dapat diilustrasikan seperti gambar (1) dimana terdapat sistem radial dengan satu pembangkit.

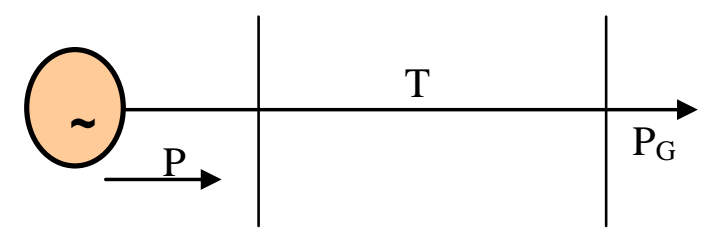

Gambar 1. Sistem transmisi radial

Mencari rugi daya $\mathrm{P}_{1}$ dengan daya yang dipasok oleh pembangkit $\mathrm{P}_{\mathrm{G}}$ ke pusat $\mathrm{P}_{\mathrm{D}}$. Diagram ekivalen dari sistem di atas adalah seperti pada gambar (2)

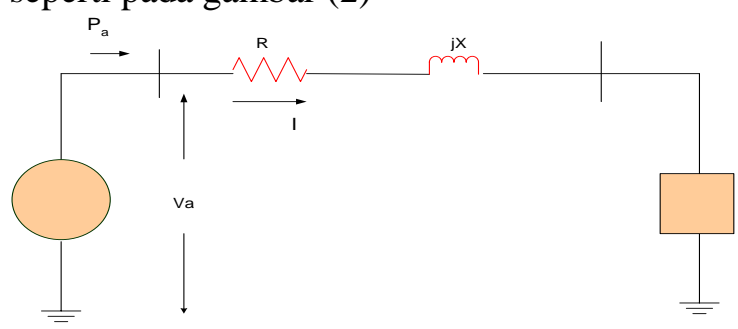

Gambar 2. Rangkaian ekivalent sistem radial

Pada gambar diperoleh rugi-rugi transmisi:

$$
P_{\mathrm{L}}=3|\mathrm{I}|^{2} \mathrm{R}
$$

dimana $\mathrm{R}$ adalah tahanan dari saluran dalam Ohm/phasa. Arus $|I|$ dapat diperoleh dari : 


$$
|I|=\frac{\mathrm{P}_{\mathrm{a}}}{\left(\sqrt{3} \quad\left|\mathrm{~V}_{\mathrm{a}}\right|\right) \cos \varphi_{\mathrm{a}}}
$$

Dengan

$\mathrm{P}_{\mathrm{a}}=$ daya yang dibangkitkan oleh generator $\mathrm{V}_{\mathrm{a}}=$ tegangan line to line (phasa ke phasa) $\cos \varphi_{a}=$ factor daya generator

Dengan asumsi ke dua persamaan di atas rugi-rugi transmisi $\mathrm{P}_{\mathrm{L}}$ diperoleh :

$$
P_{L}=\frac{\mathrm{R}}{\left|\mathrm{V}_{\mathrm{a}}\right|^{2} \cos ^{2} \varphi_{\mathrm{a}}} \mathrm{P}_{\mathrm{a}}{ }^{2}
$$

Asumsikan bahwa tegangan generator $\mathrm{Va}$ dan $\cos \varphi_{a}$ konstan maka diperoleh:

$$
\mathrm{P}_{\mathrm{L}}=\mathrm{BP}_{\mathrm{a}}^{2}
$$

dimana:

$$
B=\frac{R}{\left|V_{a}\right|^{2} \cos ^{2} \varphi_{a}}
$$

\section{Metode Penelusuran Aliran Daya}

\section{(Tracing Flow Method)}

Metode ini banyak dikenalkan oleh beberapa referensi, yang secara prinsip metode ini tidak berbeda jauh dengan perhitungan perhitungan aliran daya yang cukup dikenal seperti Metode $\mathrm{N}-\mathrm{R}$ dan metode $\mathrm{G}-\mathrm{S}$. Dari referensi tersebut yang akan di gunakan adalah referensi yang berasal dari studi yang dilakukan oleh Prof.Kirchen dan kawan kawan ( Yi Meng ,2007) . Kunci utama dari prinsip yang dikembangkannya adalah perhitungan penggunaan dari setiap titik percabangan dari sistem. Kontribusi dari generator dan beban ditentukan oleh penelusuran (tracing) daya yang mengalir disetiap percabangan dari generator menuju titik beban dimana daya tersebut dikonsumsi.

Prinsip utama yang dikembangkan oleh metode ini adalah pembagian secara proporsional (J.Bialek, 1994. p313-320). Maksudnya adalah bahwa dalam sebuah percabangan masuk akan dibagi secara proporsional dalam percabangan keluar. Porsi peran dari generator yang berbeda dalam sebuah percabangan masuk akan dibagi sama pula kepada setiap percabangan keluar yang ada.

Sebagai ilustrasi kita dapat melihat Gambar 3 berikut ini

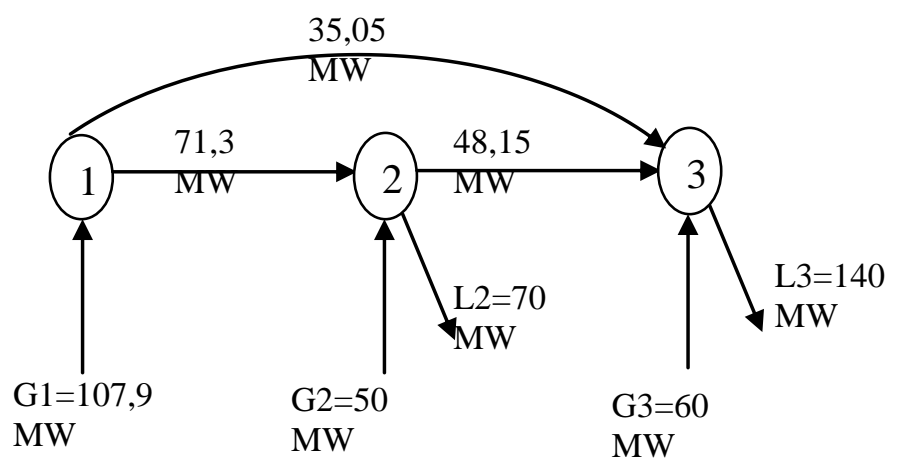

Gambar 3. Contoh Prinsip Pembagian secara Proporsional

Dari gambar pada Line m-i ada daya masuk pada titik percabangan I sebesar $P_{i}=100$ MW yang dimisalkan $60 \%$ diantaranya disupply dari Generator 1 dan $40 \%$ disuplly dari generator 2 .

Sehingga pada titik percabangan keluar line i-n terdapat kontribusi dari generator 1 ditentukan sebesar 60\% dari daya pada cabang tersebut yaitu sebesar $24 \mathrm{M}$, sedangan dari generator 2 sebesar $16 \mathrm{MB}$, begitu pula pada percabangan keluar line i-o terdapat kontribusi generator 1 terhadap dayanya sebesar $60 \%$ x $60 \mathrm{MW}=36 \mathrm{MW}$ sedangkan kontribusi generator 2 sebesar 24 MB.

Dengan asumsi pembagian secara proporsional yang cukup sederhana inilah kemudian ditentukan metode penelusuran aliran daya untuk mengetahui berapa besar aliran daya aktif dan reaktif serta rugi-rugi daya, yang dikontribusikan masing-masing generator dan beban .

Dalam metode ini beberapa konsep penting seperti sumber, bentuk /kondisi umum , 
hubungan dan bentuk jaringan. Domain/sumber didefenisikan sebagai bus yang ditentukan untuk supply generator. Sedangkan konsep common adalah penentuan bus yang berdekatan yang disupply bersama sama oleh generator yang sama. Sistem tenaga dapat disederhanakan dalam acyclic state graph dengan arus yang searah diantara comman. Gambar berikut dapat menjadi ilustrasi konsep konsep penting tersebut.

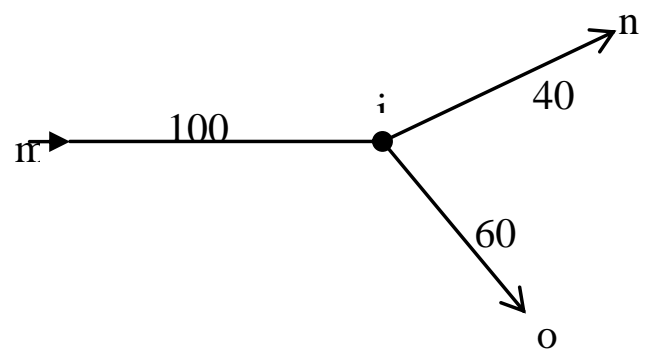

Gambar 4. Contoh Acyclic State Graph

\section{Penelusuran Aliran Daya}

Dua pendekatan yang mungkin dilakukan dalam menelusuri aliran daya adalah pendekatan pada sisi upstream dan pendekatan downstream (J.Bialek, 1996) kedua pendekatan ini didasarkan pada prinsip pembagian proporsional.

Proses perhitungan rugi-rugi dengan pendekatan ini dilakukan menggunakan rumus rumus ( J.Bialek, 1996) :

$$
\left|P_{\text {Loss }_{i-j}}\right|=C_{j i}^{\prime} P_{j} \text { atau } C_{j i}^{\prime}=\left|P_{\text {Loss }_{j-j}}\right| / P_{j}
$$

Dan

$$
\left|P_{i-j}\right|=C_{j i} P_{j} \text { atau } C_{j i}=\left|P_{i-j}\right| / P_{j}
$$

Dimana

$\mathrm{P}_{\mathrm{j}}$ adalah aliran daya pada titik $\mathrm{j}, \mathrm{P}_{\mathrm{i}-\mathrm{j}}$ dan $\mathrm{P}_{\text {loss }}$ i-j adalah aliran daya dan rugi-rugi pada line $\mathrm{j}-\mathrm{i}$.

Selanjutnya dari persamaan (5) dan (6) diperoleh :

$$
P_{i}=\sum_{j \in \alpha^{(U)}}\left(C_{j i}-C_{j i}^{\prime}\right) P_{j}+P_{G i}
$$

Dimana $\alpha_{i}^{(\mathrm{u})}$ jumlah daya yang di supply pada titik $\mathrm{I}$ dan $\mathrm{P}_{\mathrm{Gi}}$ adalah daya yang dibangkitkan ada titik I, persamaan (7) menjadi :

$$
\begin{aligned}
& P_{i}-\sum_{j \in \alpha^{(\cup)}}\left(C_{j i}-C_{j i}^{\prime}\right) P_{j}=P_{G i} \\
& \text { atau } A_{u}^{\prime} P=P_{G}
\end{aligned}
$$

Dimana $A_{u}^{\prime}$ adalah matriks $n x n$ dari upstream $\mathrm{P}$ adalah vektor aliran pada aliran daya dan $\mathrm{P}_{\mathrm{G}}$ adalah vector daya pada bus pembangkitan. Dimana batasan bagian dari $(\mathrm{I}, \mathrm{j})$ adalah :

$$
\left[A_{u}^{\prime}\right]_{i j}=\left\{\begin{array}{l}
1 \\
-C_{j i}=-\left|P_{j-i}\right| / P_{j} \\
0
\end{array}\right.
$$

Sehingga :

$$
P_{i}=\sum_{k=1}^{n}\left(A_{u}^{\prime-1}\right)_{i k} P_{G k}
$$

Dan

$$
P_{L i}=\frac{P_{L i}}{P_{i}} P_{i}=\frac{P_{L i}}{P_{i}} \sum_{k=1}^{n}\left(A_{u}^{\prime-1}\right)_{i k} P_{G k}
$$

$P_{i-j}=\frac{P_{i-j}}{P_{i}} P_{i}=\frac{P_{i-j}}{P_{i}} \sum_{k=1}^{n}\left(A_{u}^{\prime-1}\right)_{i k} P_{G k}$

Selanjutnya Kontribusi generator I pada beban $\mathrm{j}$ dan kontribusi generator I pada line $\mathrm{j}$ $-\mathrm{k}$ adalah :

$$
\alpha_{j k}=\frac{\left(A_{u}^{\prime-1}\right)_{j i} P_{G i}}{P_{j}}
$$


$\beta_{i j}=\frac{\left(A_{u}^{\prime-1}\right)_{j i} P_{G i}}{P_{j}}$

\section{METODE PENELITIAN}

\section{Lokasi Dan Waktu Penelitian}

Penelitian ini dilaksanakan di daerah wilayah kerja PT. PLN (Persero) Wilayah Sultanbatara yang meliputi Propinsi Sulawesi Selatan , Sulawesi Barat dan Sulawesi Tenggara. Waktu penelitian dimulai pada bulan April 2009 dan selesai pada Awal Juli 2009 atau kurang lebih selama 3(tiga) bulan.

\section{Jenis Data dan Sumber Data}

Dalam penelitian ini data yang di perlukan terdiri dari

\section{Data Primer}

- Data model jaringan sistem tenaga terinterkoneksi atau data contoh sistem dalam IEEE.

- Data tegangan , impedansi penghantar, panjang saluran, daya serta faktor daya tiap bus.

- Data Generator marginal price , total pembangkitan serta total beban.

\section{Data Sekunder}

Merupakan data tambahan yang diperlukan oleh peneliti untuk mendapatkan gambaran dan keterangan yang lebih lengkap ataupun sebagai data pembanding dari hasil yang diperoleh nantinya. Data ini bisa merupakan telaah jurnal, dokumen atau penelitian penelitian terdahulu yang berhubungan dengan penelitian ini.

\section{Instrumen Penelitian}

Instrumen yang digunakan dalam penelitian ini adalah Perangkat lunak Perhitungan Matematika , Matlab Ver 7.0.4 sebagai alat bantu analisis dan perhitungan dari data-data yang ada.

\section{Prosedur Pengumpulan Data}

Data yang dibutuhkan dalam penelitian ini adalah data yang berhubungan dengan perhitungan aliran daya dan Biaya dalam sistem transmisi. Tahapan pengumpulan data yang akan dilakukan antara lain :

a. Studi pustaka/literatur, meliputi identifikasi kondisi umum sistem kelistrikan.

b. Observasi meliputi Pengambilan datadata yang dibutuhkan dan bisa diperoleh pada Area Penyaluran dan Pengaturan Beban (AP2B) PT. PLN (Persero) Wilayah Sultanbatara .

\section{Teknik Analisis Data}

Teknik Analisis data merupakan tahapan yang sangat penting dalam penelitian dimana data yang diperoleh di kelompokkan, kemudian digunakan dalam perhitungan, adapun tahapan penyelesaian penelitian ini adalah :

1. Perhitungan dan penentuan aliran daya berdasar pada data dan kondisi yang ada selama penelitian atau pada sampel waktu yang ditentukan. Jika diperlukan akan dilakukan perhitungan kembali dengan menggunakan program Fortran atau Matlab.

2. Perhitungan kontribusi generator dan beban terhadap aliran daya dan rugi irugi menggunakan metode penelusuran aliran daya (Tracing Power flow Method). Pada bagian ini akan dicari parameter kofisien kontribusi dari Generator terhadap rugi-rugi dari sistem serta besar kontribusinya .

\section{Kerangka Pikir}

Didasarkan pada kenyataan bahwa untuk memenuhi kebutuhan listrik diperlukan perluasan sistem baik pembangkit maupun transmisi serta disribusinya yang konsekwensinya adalah biaya yang dibutuhkan untuk itu serta nilai balik yang layak namun tidak memberatkan masyarakat menyebabkan penentuan tarif listrik menjadi penting.

Salah satu faktor penting untuk menentukan besar biaya yang menjadi pertimbangan penentuan tarif listrik adalah rugi-rugi, selain dari biaya operasi, karenanya diperlukan analisa untuk menentukan rugi transmisi tersebut. 
Dari analisa ini diharapkan dapat ditentukan kontribusi Generator terhadap rugi-rugi, sehigga kemudian penentuan biaya rugi-rugi menjadi lebih baik dengan menghitung berdasarkan nilai kontribusi terhadap rugi daya serta biaya produksi generator tersebut.

\section{IV.HASIL DAN PEMBAHASAN}

Penentuan pembagian proporsional untuk rugi-rugi daya pada sistem Sulawesi selatan ini dimulai dengan menentukan besar daya pada masing masing line dalam sistem transmisi melalui studi aliran daya.

Untuk memudahkan melakukan identifikasi maka dilakukan penomoran bus pada masing-masing gardu induk, penomoran dilakukan dengan mengurutkannya dari bus dengan jumlah pembangkitan terbesar yaitu pada GI Sengkang dengan nomor kode bus 1 sampai bus dengan normor kode bus 43 yaitu pada GI Bontoala.

Selanjutnya pemberian kodifikasi bus tersebut seperti Tabel Berikut ini :

Tabel 4.3. Penomoran bus pada sistem Sulsel

\begin{tabular}{|c|c|}
\hline Nama Gardu Induk & No Rel \\
\hline & \\
\hline SENGKANG & 1 \\
\hline BAKARU & 2 \\
\hline TELLO 150 & 3 \\
\hline TELLO 30 & 4 \\
\hline SUPPA & 5 \\
\hline TELLO 70 & 6 \\
\hline BILI BILI & 7 \\
\hline TELLO 34,5 & 8 \\
\hline PALOPO & 9 \\
\hline MALEA & 10 \\
\hline MAMUJU & 11 \\
\hline PINRANG & 12 \\
\hline PLTU JENEPONTO & 13 \\
\hline BARRU & 14 \\
\hline BARAWAJA & 15 \\
\hline BORONGLOE & 16 \\
\hline MAROS & 17 \\
\hline PARE PARE & 18 \\
\hline POLEWALI & 19 \\
\hline BOSOWA & 20 \\
\hline TONASA & 21 \\
\hline SDRAP & 22 \\
\hline
\end{tabular}

\begin{tabular}{|c|c|}
\hline Nama Gardu Induk & No Rel \\
\hline & \\
\hline BULUKUMBA & 23 \\
\hline JENEPONTO & 24 \\
\hline MAJENE & 25 \\
\hline PANGKEP 70 & 26 \\
\hline MAKALE & 27 \\
\hline SIWA & 28 \\
\hline TP 57/58 & 29 \\
\hline WOTU & 30 \\
\hline MALILI & 31 \\
\hline TALLASA & 32 \\
\hline DAYA & 33 \\
\hline SUNGGUMINASA & 34 \\
\hline TANJUNG BUNGA & 35 \\
\hline SOPPENG & 36 \\
\hline BONE & 37 \\
\hline MANDAI & 38 \\
\hline TELLO LAMA 70 & 39 \\
\hline TALLO LAMA & 40 \\
\hline PANAKKUKANG & 41 \\
\hline PANGKEP & 42 \\
\hline BONTOALA & 43 \\
\hline & \\
\hline
\end{tabular}

Dari penomoran tersebut kemudian dengan menggunakan data yang diberikan oleh AP2B sistem Sulawesi selatan yaitu data keadaan sistem Sulawesi selatan pada pada 10 maret 2008, diantaranya dalam bentuk data admittansi, diagram garis sistem Sulawesi selatan dan Barat, kemudian dilakukan studi aliran daya terhadap sistem untuk mendapakan aliran daya sistem tersebut. Data yang diberikan ini dipilih karena pada tanggal tersebut kondisi beban puncaknya relative tinggi dibandingkan dengan kondisi hari hari lainnya serta kondisi sistem yang belum memiliki tambahan pembangkit baru. Untuk membuat 2(dua) keadaan yang berbeda dari sistem dibuat studi aliran daya, yang pertama yaitu berdasarkan keadaan pada tanggal tersebut, sementara keadaan kedua diasumsikan salah satu pembangkit yang direncanakan telah masuk dalam sistem dan bekerja pada pembangkitan maksimalnya. Hal ini diharapkan bisa menggambarkan kondisi rugi-rugi yang maksimal yang mungkin terjadi pada sistem Sulawesi selatan.

Dua keadaan tersebut yaitu keadaan 1 dengan total daya yang dibangkitkan 579 MW serta keadaan 2 dengan total daya yang dibangkitkan sebesar $679 \mathrm{MW}$

Hasil dari studi aliran daya ini digunakan untuk menentukan berapa rugi-rugi tiap line dalam sistem tenaga Sulawesi selatan sesuai data yang digunakan. Kode rel awal adalah kode rel dimana aliran daya keluar dari bus dan kode rel akhir adalah kode rel dimana aliran daya masuk ke bus.

Selanjutnya besar daya per line ditentukan untuk menjadi input bagi matriks distribusi daya A.

Dari data yang ada ini kemudian dibentuk Matris A ( Lampiran 3 ) sebagai matriks yang akan digunakan untuk menentukan Kontribusi Generator sesuai persamaan 2.25 terhadap rugi-rugi selanjutnya. Matriks ini selanjutnya di invers dan hasil inversnya digunakan untuk menghitung kontribusi sesuai persamaan 2.28. sehingga diperoleh hasil perhitungan Kontribusi Generator.

a. Kapasitas Pembangkit dan Kontribusi Perbandingan antara Kapasitas Pembangkit dan rugi daya dapat dilihat dalam Grafik berikut ini : 
ISSN 1979-7540

Kontribusi ( MW)

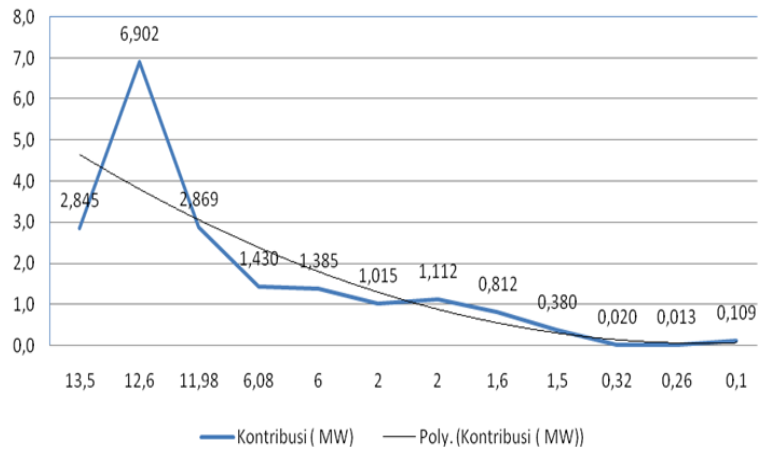

a. Keadaan 1

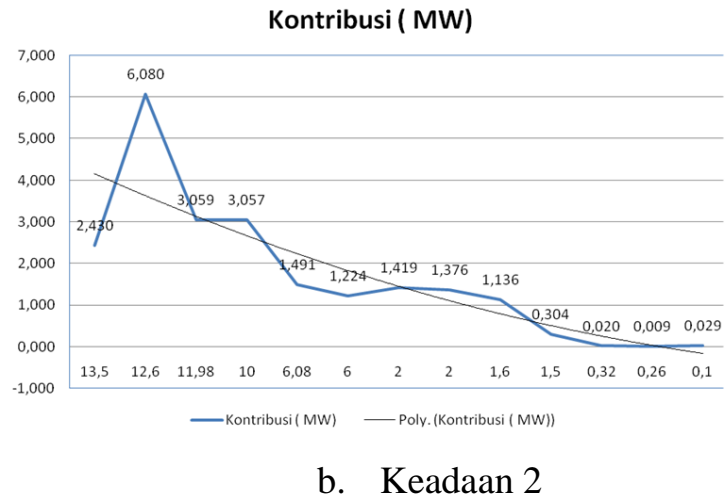

Grafik 4.1. Perbandingan Daya Pembangkit dan Kontribusi Generator

Dari grafik terlihat bahwa ada kecenderungan semakin kecil daya yang dibangkitkan maka kontribusi pembangkit tersebut terhadap rugi-rugi adalah lebih kecil, pada pembangkit dengan daya yang cukup besar ada kecenderungan untuk kontribusi tersebut jumlahnya berbanding terbalik, ini lebih banyak disebabkan karena banyaknya jaringan transmisi yang terhubung ke Pembangkit tersebut, selain dari panjangnya jaringan yang menghubungkan pembangkit besar di utara dengan pusat beban di selatan. Seperti pada Pembangkit Bakaru, kontribusi terhadap ruginya 6,9 MW (keadaan 1) dan 6,08 MW (Keadaan 2 ) karena kontribusi generator tersebut kepada semua line transmisi yang menghubungkannya dengan pusat-pusat beban, Demikian pula dengan pembangikit di Sengkang. Sedangkan Pembangkit Tello 150,kontribusi terhadap rugi-ruginya cukup besar walaupun berada didaerah yang dekat dengan pusat beban disebabkan karena banyaknya jaringan transmisi yang terhubung dengan bus tersebut.

b. Perbandingan kontribusi pada dua keadaan

Berdasarkan tabel 4.6 - 4.9 dapat dilihat perbandingan kontribusi pembangkit terhadap rugi daya.

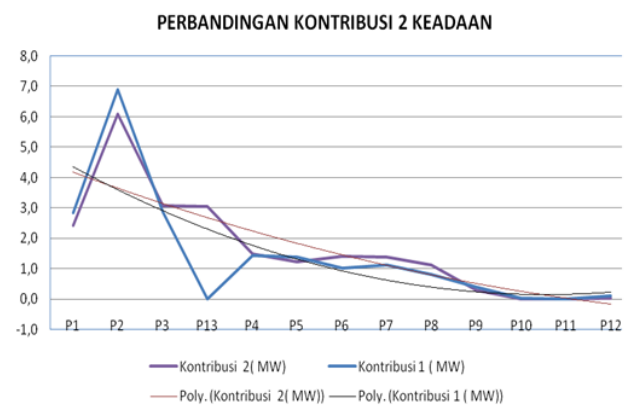

Grafik 4.3. Perbandingan kontribusi dua keadaan daya pembangkitan

Dari grafik diketahui perubahan kontribusi pembangkit/generator terhadap rugi-rugi memiliki kecenderungan untuk mengikuti daya yang dibangkitkan, Untuk sistem Sulawesi selatan, naiknya jumlah daya total yang dibangkitkan dikarenakan bertambahnya pembangkit/generator menyebabkan naiknya rugi-rugi, namun komposisi kontribusi terhadap rugi-rugi akan berubah karena pembangkit/generator yang baru masuk dalam sistem akan berkontribusi pula dalam rugi-rugi tersebut.

\section{KESIMPULAN}

1. Total rugi-rugi daya sistem Sulawesi selatan adalah sebesar 19,46 MW untuk total daya sebesar $579 \mathrm{MW}$ atau sebesar kurang lebih 3,36 \% dari total daya yang dibangkitkan, sedangkan untuk keadaan 2 dengan daya sebesar 679 MW diperoleh rugi daya sebesar 21,64 MW atau sebesar $3,187 \%$.

2. Kontribusi proporsional terbesar terhadap total rugi daya pada sistem Sulawesi selatan pada keadaan 1 adalah oleh Pembangkit/Generator Bakaru, yaitu 
sebasar 35,14 \% dari total rugi rugi, sementara yang terkecil adalah PLTD Mamuju sebesar 0,07\%. Sedangkan pada keadaan 2 , kontribusi proporsional terhadap rugi daya terbesar adalah 28,1 $\%$ oleh Pusat Pembangkit Bakaru dan yang terkecil adalah $0,042 \%$ pada PLTD Mamuju.

3. Secara umum tampak bahwa semakin kecil daya yang dibangkitkan kontribusi pembangkit tersebut terhadap rugi rugi daya semakin kecil pula. namun pada pembangkit dengan daya yang cukup besar ada kecenderungan untuk kontribusi tersebut jumlahnya berbanding terbalik, hal ini lebih banyak disebabkan karena banyaknya jaringan transmisi yang terhubung ke Pembangkit tersebut dan panjangnya jaringan yang harus dilewati hingga sampai pada pusat beban.

\section{PUSTAKA}

Gitosusastro,Santoso. 2007. Kesiapan PT.PLN Dalam Penyediaan dan Penyaluran Energi Listrik Nasional. Seminar Nasional Teknik Ketenagalistrikan - SNTK. Makassar.

Harun, Nadjamudin. 2007. Perencanaan Sistem Tenaga Listrik - Materi Kuliah Teknik Energi Listrik. Tidak Diterbitkan. Program Pascasarjana Universitas Hasanuddin. Makassar.

Amri, I. (2010, August 5). PERTIMBANGAN PENGARUH BEBAN DALAM PERANCANGAN PEMBANGKITAN SISTEM TENAGA LISTRIK. http://doi.org/10.17605/OSF.IO/CPK7 $\mathrm{N}$

J.Bialek. 1996. Tracing The Flow Of Electrcity. IEEE Proceding ON Generation , Transmission and Distribution, Vol 143 No.4 1996.

Meng Yi and Benyamin Jeyasurya. 2007. Investigation of Transmission Cost Allocation Using Power Flow Tracing Method. IEEE.
Menteri Energi dan SDM. 2007. Kebijakan Penyediaan dan Penyaluran Energi listrik Nasional. Seminar Nasional Teknik Ketenagalistrikan - SNTK. Makassar.

Molina , Yuri P. Ricarda H.Prada dan Osvaldo R Saavedra. 2007. Allocation Of TRnsmission Loss Cost Using Game Theory. IEEE.

Momoh, James A. 2001. Electrical Power System Aplication Of Optimation. Marcel Dekker Inc ,New York.

Saadat, Hadi. 1999. Power System Analysis. McGraw-Hill International Edition, Singapore.

Siahkali,H. 2007. Allocation Of Transmiision Lost Cost With Teaceble Flow Method in Power System Network. IEEE PES Power Africa 2007 Confrence and Exposition, Johannesburg, South Africa.

Stevenson, W.D. 1994. Anaisis Sistem Tenaga Listrik, Penerbit Erlangga, Surabaya.

Wood, Allen $\mathrm{J}$ and Bruce F. Wollenberg. 1984. Power Generation Operation and Control. John Wiley and Sons, New York. 